\title{
LIFELINES IN STUDIES ON BIOGRAPHIC DETERMINANTS OF DECISIONS TO TAKE UP PHD STUDIES AT A TECHNICAL UNIVERSITY
}

\author{
Emilia Mazurek \\ Wroclaw University of Science and Technology, Department of Humanities and Social Sciences \\ Pl. Grunwaldzki 11, 50-377 Wroclaw, Poland \\ Olena Vynoslavska \\ National Technical University of Ukraine "Igor Sikorsky Kyiv Polytechnic Institute”, Department of Sociology and Law \\ Prospect Peremogy 37, 03056 Kyiv, Ukraine
}

\begin{abstract}
The article aims at presenting the potential and limitations of lifelines as a method used to collect biographic data. The lifeline facilitates recollection and sequencing of personal events. For this reason, it is helpful both for a person trying to recreate their own life history, and for a researcher who analyses the biography of such a person. The lifelines can be triangulated with other data collection methods to confirm and complete a life history. A sample lifeline from a study of $\mathrm{PhD}$ students at the main technical universities in Poland and Ukraine used to demonstrate the application of this method to research of biographic determinants of important life decisions.
\end{abstract}

\section{KEYWORDS}

biographical research, lifeline, academic teacher, higher education, $\mathrm{PhD}$ studies

\section{INTRODUCTION}

The positivist doctrine of science provided social scientists with some procedures of conducting research which were to bring academics closer to objective cognition and ensure the scientific character of their study and exploration. "The codes of methodological norms standardized researchers' activities to resemble an industrial production line, making sure that they conform to industrial values of the times of modernism: efficiency, recurrence, and reliability" (Malewski 2017b, p. 117). Qualitative studies which have been dynamically developing for the last several decades, "extend the barriers of researchers' methodological freedom" (Malewski 2017b, p. 118), forcing academics to be independent, reflective, imaginative, and courageous in their work (Malewski 2017a, 2017b). This is expressed both in researchers' actions undertaken at the time of collecting data, as well as during data analysis and interpretation-actions which mostly involve looking for paths leading to cognition, understanding, and explanation.

Biography studies are based on the analysis of (auto)biographical narrations - stories about one's own or another person's life. The main method of collecting data by biography researchers is a narrative interview or studying memoirs, diaries, (auto)biographies, (auto)biographic essays, etc. Another useful (though applied less often) method of obtaining and analysing data is the usage of lifelines.

„Life histories are data collection strategies that detail an individual's life. Lifelines are a visual depiction of a life history, displaying events in chronological order and noting the importance, or meaning, of events" (Gramling, Carr 2004, p. 207). The lifeline „can serve as retrospective and holistic representations of experiences, helping participants link past experiences with subsequent actions" (Arnault, Shimabukuro 2011, s. 315). In literature, the concept of lifeline is often used interchangeably with a timeline (see e.g. Berends 2011). Elzette Fritz and Grethe van Zyl (2015) differentiate these two terms, explaining that timelines can be contructed in order to capture a certain sequence of events related to some kind of 
experience and can be created not only by the author participating in these events. In turn, drawing a lifeline allows a person to think about their own life history and situate selected events (which were momentous, important in life) on a lifeline. When adopting such a differentiation, it can be claimed that biography researchers creating a visual image of the course of life independently (based on previously collected study material) or with a narrator, use a timeline (though they sometimes they also call it a lifeline). Timelines are very useful in extensive research projects with a large number of study participants and/or when the collected study material is extensive. Timelines also allow to keep data in order and compare it more easily. In turn, researchers asking study participants to visually present their life history use lifelines. Preparing a lifeline is a perfect introduction to the next stage of the study and helps to reflect upon one's life, put it in order, choose the key (from a certain perspective, at a specific time) events and find their meaning, show them in a wider context; it also helps to prepare to construct an autobiographic narration. Most frequently, researchers use lifelines and timelines as an introduction to the construction of an autobiographic narration or to put in order an already prepared one.

A different approach is proposed by Hanne Kirstine Adriansen (2012) who claims that her method of collecting data is a timeline interview. Constructing a timeline is a joint effort of both the narrator and the researcher. The line is created during an interview and new information is added on the go. The narrator decides which event starts and ends the line. Not always is it a line showing the course of life from birth to the interview. Sometimes, the narrator may place certain events from before they were born on the line, as well as mark something in the future. An image showing a timeline is often divided into two parts-the first one showing the most important events listed by the narrator, and the other one which includes suplementary data to key events. Looking at the line, we can find several sections presenting different histories which affect one another. During the interview, the narrator may find certain relations between these historiesconnections which they had not noticed before. Thus, the analysis of such a narration starts already during the interview (Adriansen 2012).

This article aims at presenting the potential and limitations of lifelines as a method used to collect biographic data. This concept will be demonstrated based on studies conducted among PhD students at the main technical universities in Poland and Ukraine.

\section{METHODS AND SAMPLE}

Perceiving a teacher as a researcher "independent in their cognition as a reflective, creative scientist of their own practice, of an open mind, critical and searching in their professional development and competences" (Dróżka 2014, p. 229) inspired us to conduct comparative studies on biographic determinants of engineers' decisions to start a $\mathrm{PhD}$ program at a technical university and, at the same time, to become an academic teacher. The main objective of this study was to find biographic determinants of a decision to start $\mathrm{PhD}$ studies at a technical university. By conducting our study, we also wanted to determine the importance of young people's life experience and biography in making important life decisions. Our aim was to encourage $\mathrm{PhD}$ students to reflect upon the history of their life in the context of an already made decision to start a PhD program.

In order to answer the presented research questions, we conducted a biography study based on the material of lifelines and autobiographic essays prepared by $\mathrm{PhD}$ students at the Wrocław University of Science and Technology and the National Technical University of Ukraine in Kiev. The group of studied persons was selected according to the principle of purposive sampling. The study included 56 participants (Poland: 28 persons, including 10 women; Ukraine: 28 persons, including 2 women) of 23 to 30 years of age. The average age of a participant was 25 . The majority of participants came from a big city (29 persons), 14 participants - from a medium-size town, 9-from a small town, and 7-from the countryside. The $\mathrm{PhD}$ students who participated in the study were working within the following disciplines: architecture, electronics, IT, management, automatics and robotics, mechanical engineering, and biotechnology.

The $\mathrm{PhD}$ students were asked to draw their lifelines and mark them with all elements (events, persons, places, etc.) which they considered important in their biographies for the decision to take up $\mathrm{PhD}$ studies and the role of academic teachers. Aware of the fact that many engineers decide to obtain a $\mathrm{PhD}$ degree not because they see their future in academia, developing in science and teaching at a university, but because they want to develop their career in industry and business, we also asked to include this factor in the prepared 
materials. Lifelines were supposed to serve as an introduction to the task of writing an autobiographic essay in which participants could elaborate on elements marked on their lifelines.

A significant majority of the $\mathrm{PhD}$ students asked to prepare their lifelines and autobiographic essays consented to such conditions. Interestingly, not all $\mathrm{PhD}$ students submitted the materials they had prepared, as they considered these materials too personal. The $\mathrm{PhD}$ students participating in the study often stressed that the reflection upon their own biographies was an interesting lesson for them, the first moment when they consciously reflected upon their lives and decisions in the context of analysing their whole autobiographies.

The analysis and interpretation of the studied material (i.e. lifelines and autobiographic narrations) were conducted in accordance with a method of a multi-level analysis and hermeneutic interpretation (Kruchowska 2010). Lifelines and autobiographic essays were prepared in participants' mother tongues (i.e. in Polish and Ukrainian). That is why the first stage of analysis (i.e. coding, selecting theme motifs and key categories related to the studied problem in every narration and lifeline) was conducted by each of us individually. At the second stage, we worked together to look for categories that were common to PhD students of the Wrocław University of Science and Technology and of the National Technical University of Ukraine in Kiev, and for categories that differed in these two groups. Data were organized under each category and reviewed, noting the commonalities and differences. Then, we performed a so-called external interpretation, within which we compared the discovered meaning to theoretical models and empirical studies on biographic determinants of life decisions. Thus, the study was of an explorative character, with an inductive approach to a qualitative analysis, assuming no initial categorizations around which the analysis of data is conducted (Gramling, Carr 2004; Riessman 2005).

The results of the study on biographic determinants of decisions about taking up PhD studies at technical universities will be presented in a different paper. This text presents the conclusions resulting from a formal analysis of PhD students' lifelines and concentrates on presenting a potential and limitations of a lifeline as a research method used to collect biographic data. We focus our reflections on the analysis of a temporal and visual level of lifelines of $\mathrm{PhD}$ students participating in our study.

\section{RESULTS}

\subsection{A temporal level of a lifeline}

A biography is "an individual destiny of a person, extended between their birth and death (time of life), and, at the same time, the act of this person's own creative activity" (Lalak 2010, p. 39). A human being, when telling a story of their life, is not able to reconstruct all events, and has to choose those which they for some reason consider important to include, mention, and interpret. Reflecting upon past events also encourages us to create plans for the future, look for relations between the past and present, and find the sense and meaning of past events from a time perspective (see: Demetrio 2000). That is why, as Elżbieta Dubas claims, "biographic narrations show three, and sometimes even four time perspectives: past, present, future, and eternity" (Dubas 2014, p. 22).

The analysis of lifelines prepared by $\mathrm{PhD}$ students included a close look at their temporal dimension. Each lifeline presented a person's past, which constituted the longest part in drawn schemes of life paths. The remaining time perspectives were not so obvious. The present time was shown by 48 persons, future by 20 persons, and eternity was marked symbolically by 2 persons (see tab. 1 ).

Past events were visualized on lifelines prepared by study participants by marking birth ( 24 persons), childhood ( 32 persons), adolescence ( 46 persons) and early adulthood (56 persons). All lifelines are the most detailed in periods related to formal education (starting with primary school, up to academic education), with the university level being the richest in details. They reveal both the learning process that run unconsciously, spontaneously, non-systematically, and learning resulting from intentional actions placed in formal education (see: Mazurek 2015). 
Table 1. Time perspectives included on lifelines Source: authors' own study

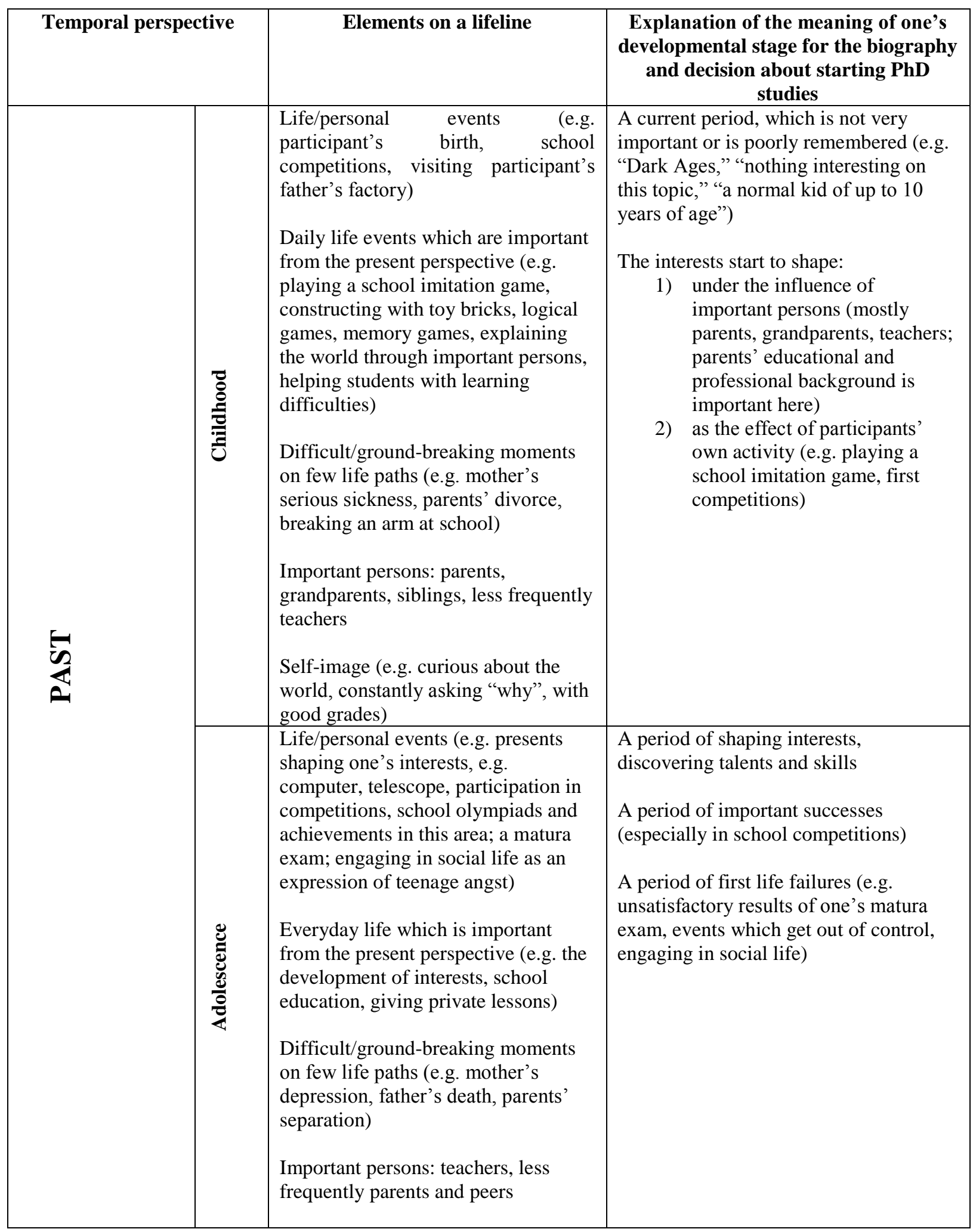




\begin{tabular}{|c|c|c|c|}
\hline & 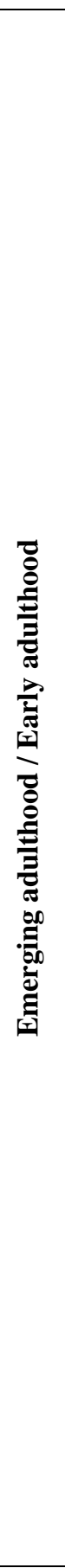 & $\begin{array}{l}\text { Life/personal events (e.g. selecting a } \\
\text { field of studies, selecting a specialty, } \\
\text { defending one's thesis, finding one's } \\
\text { life partner, getting married, first job, } \\
\text { birth of one's child, networking with } \\
\text { an important person at the } \\
\text { university-usually a thesis } \\
\text { supervisor, participating in first } \\
\text { research projects and internships } \\
\text { abroad) } \\
\text { A global event (war in Donbass)- } \\
\text { currently on } 3 \text { lifelines of PhD } \\
\text { students from Ukraine } \\
\text { Everyday life which is important } \\
\text { from the present perspective (e.g. } \\
\text { studying and having difficulties in } \\
\text { that area, passing exams, giving } \\
\text { private lessons, working } \\
\text { professionally) } \\
\text { A self-image (e.g. I am no longer the } \\
\text { best, I willingly help other students } \\
\text { with studying) } \\
\text { Difficult/ground-breaking moments } \\
\text { on few life paths (e.g. participant's } \\
\text { sickness, separation with a close } \\
\text { person, giving birth to a child, } \\
\text { supervisor's death) } \\
\text { Important persons: academic teachers } \\
\text { (most frequently PhD thesis } \\
\text { supervisor), less frequently-partners } \\
\text { and parents } \\
\text { Numerous lifelines showing this } \\
\text { period spread into two or more } \\
\text { directions (e.g. PhD studies and } \\
\text { professional work, doing two fields } \\
\text { of studies, studying at a university } \\
\text { and having a hobby) }\end{array}$ & $\begin{array}{l}\text { A period of life with a lot of possibilities } \\
\text { for development } \\
\text { A period rich in decisions which are } \\
\text { important in life, and the need to face the } \\
\text { consequences of one's own decisions }\end{array}$ \\
\hline 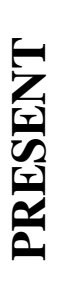 & & $\begin{array}{l}\text { A graphically presented moment of } \\
\text { creating a lifeline, most frequently } \\
\text { complemented with a question (e.g. } \\
\text { Where did it all start? How did I get } \\
\text { here? What am I doing here?) }\end{array}$ & $\begin{array}{l}\text { Participating in research as an event } \\
\text { initiating reflection; a moment which is } \\
\text { frequently presented as the first one in } \\
\text { life when we consciously and deeply } \\
\text { think about one's life path and its } \\
\text { connections with a decision to start } \\
\text { tertiary level studies }\end{array}$ \\
\hline
\end{tabular}




\begin{tabular}{|l|l|l|}
\hline & $\begin{array}{l}\text { Presented as a complementary part of } \\
\text { a lifeline with many different } \\
\text { methods: } \\
\text { 1) } \begin{array}{l}\text { an uncompleted, empty } \\
\text { lifeline which is an } \\
\text { extension of previously } \\
\text { presented periods } \\
\text { a line with marked years } \\
\text { with anticipated events, } \\
\text { plans for the future }\end{array}\end{array}$ & $\begin{array}{r}\text { Future presented as: } \\
\text { 1) hope, } \\
\text { 2) a precise plan, } \\
\text { 3) something unknown. } \\
\text { a symbolically marked } \\
\text { objective to strive for } \\
\text { question marks }\end{array}$ \\
\hline & $\begin{array}{l}\text { Symbols associated with death (i.e. } \\
\text { grave at the end of a lifeline, } \\
\text { participant's own death as a point } \\
\text { which ends a lifeline) }\end{array}$ & $\begin{array}{l}\text { Eternity presented symbolically, with no } \\
\text { description or explanation of how it is } \\
\text { understood }\end{array}$ \\
& & \\
\hline
\end{tabular}

\subsection{A visual aspect of a lifeline}

The study participants independently decided on their method to graphically present their lifelines, which resulted in a huge diversity of adopted solutions in this area.

The lifelines usually took the form of a straight horizontal or a vertical line or, rarely, a wave on which participants marked points with short descriptions naming events or persons involved. The majority of lifelines prepared that way also included the years when specific events took place. The future was marked with a dotted line, ellipsis, or a question mark. Some of the participants decided to present their lifelines metaphorically as a path (a straight one or a path with numerous turns, sometimes also with bifurcations or intersections), on which the most important events were marked. Another way to present one's lifeline was to portray one's self at specific stages of life (e.g. a baby in a sleeping bag, an infant playing with toy bricks, a boy with a computer, a group of people, a man pushing down a pram) or use small drawings symbolizing events/persons and separated with arrows which show the course of life. One lifeline consisted of six houses symbolizing the subsequent stages of life, connected with footsteps leading from one house to another.

Many lifelines show small drawings presenting:

- life experiences (e.g. baby's sleeping bag as a symbol of birth, suitcases as a symbol of moving home, wedding rings as a symbol of getting married, mountains as a symbol of one's passion),

- persons (usually portraying the participant, sometimes close relatives, friends, teachers, students, or even other persons who inspire the participant to think about their lifeline),

- places (e.g. home, kindergarten, shelter),

- emotions (e.g. a bomb by the question: “Am I pregnant?!” or a heart between two people, a smiling or sad face),

- reflections (e.g. a drawing of a dog and leash with a comment at the side saying "I am not on a leash"; then a ship sailing with a small fish below it and a person on the bottom with a comment under the drawing: "I hit rock bottom"; then, a figure of a person and a question mark, with a question "What am I doing" under the drawing; then, a clenched fist with a part of a person visible in the fist with a comment below saying "I am holding myself together"; many 
lifelines feature question marks symbolizing the need to make a decision, make a choice, or think about the future).

\section{CONCLUSION}

Changes occurring in methodological practices in social sciences are visible, among others, in weakening the potential of a scientific method and strengthening the position of a researcher (Malewski 2012). A researcher finds individual, often original, research solutions (Pryszmont-Ciesielska 2016) to get to know, describe, and explain the social world with its contextual character and the diversity of how people perceive and understand it. Thus, a researcher seeks unconventional paths providing them with an insight into their social reality. As Malewski claims, "Researcher's reflection, imagination, and competence determine whether the used methods and techniques lead to the achievement of assumed cognitive and practical objectives. It is the only criterion of validating methodological correctness of conducted studies" (Malewski 2012, p. 43).

In our studies, the use of a lifeline was a pretext to inspire $\mathrm{PhD}$ students to reflect on their life histories and made decisions (see also: Vynoslavska 2003; Sladek 2016). This function has been fulfilled, which is visible in the created lifelines and comments shared by the study participants. For reviewed students, their lifeline creation was creative work combined with deep reflection - sometimes such a deep one, that some participants refused to share their creations with the researchers. The created lifelines were extremely diverse in terms of their content and form. What was surprising, many lifelines included symbols which graphically presented different life (also ground-breaking) experiences, emotions, the meaning of life events for one's biography. Some lifelines included comments which served as an attempt to start a dialog with the researchers.

We did not notice any significant differences in the lifelines prepared by PhD students from Poland and Ukraine. However, among the most important differences are the presence of global events only on the lifelines of $\mathrm{PhD}$ students from Ukraine, more precise plans for the future of Ukrainians, a greater saturation of emotions as well as events unrelated to education on the lifelines of Polish $\mathrm{PhD}$ students.

Lifelines have a potential in studying biographies, as they are helpful both for a person trying to recreate their own life history, and for a researcher who analyses the biography of such a person. Lifelines are a bridge connecting one's real experiences and their memory and recreation, as well as the act of telling the story of these experiences (Berends 2011, p. 2). A graphic representation of one's own biography can help in putting one's life history in order and organizing it, which requires some reflection. Inspiring reflection and self-awareness of a study participant is an educational and therapeutic function of biography studies (see: Dominice 2000, Lalak 2010, Mazurek 2017).

The process of creating lifelines may occur on different stages of biography studies. Drawing a lifeline may precede the construction of an autobiographic narration or function as its introduction, but a lifeline can also be its final stage. A lifeline can also be created at the time of constructing a narration. It is also an interesting solution to draw a lifeline before telling one's life story, and then modifying the lifeline depending on the narration.

Lifelines are especially helpful as a tool to conduct extended research projects with a large number of participants and/or extensive study material. However, it would be difficult to use a lifeline as the one and only study method, as different elements presented on a lifeline are too symbolic. Thus, a narration is needed to provide a description, interpretation, and a meaning for presented events, persons, places, etc. We see a huge potential in a lifeline as a method of collecting biographic data, but also as a didactic tool which can be used during biography workshops and other forms of classes. It can support self-creation and selfdevelopment (Goodson, Scherto 2011; Sladek 2017).

\section{REFERENCES}

Adriansen, H.K. (2012). Timeline interviews: A tool for conducting life history research. Qualitative Studies. 3(1), 40-55.

Arnault, D. S., Shimabukuro, S. (2011). The Clinical Ethnographic Interview: A user-friendly guide to the cultural formulation of distress and help seeking. Transcultural Psychiatry. 49(2), 302-322. 
Berends, L. (2011). Embracing the Visual: Using Timelines with In-depth Interviews on Substance Use and Treatment. The Qualitative Report. 16(1), 1-9.

Dominice, P. (2000). Learning from our lives: using educational biographies with adults. San Francisco: Jossey Bass.

Dróżka, W. (2014). Badania biograficzne w pedeutologii. Stan i kierunki ewolucji. Przegląd Badań Edukacyjnych. 19(2), 211-234.

Dubas, E. (2014). Czas, biografia i badania biograficzne - różnorodność kontekstów w andragogicznej perspektywie. Edukacja Dorosłych, 2(71), 13-27.

Goodson, I. (2006). The Rise of the Life Narrative. Teacher Education Quarterly. 33(4), 7-21.

Goodson, I., Scherto, G. (2011). Narrative Pedagogy. Life History and Learning. New York: Peter Lang Publishing.

Gramling, F. L., Carr, L. R. (2004). Lifelines: a life history methodology. Nursing Research. 53(3), 207-210.

Fritz, E., van Zyl, G. (2015). Lifelines. A Visual Exploration of the Past in Order to Guide the Journey into the Future [in:] M. McMahon, M. Watson (eds.). Career Assessment. Qualitative Approaches. Sense Publishers, 89-96.

Kruchowska, E. (2010). Metoda wielostopniowa analizy interpretacji hermeneutycznej materiału empirycznego. [in:] M. Straś-Romanowska, B. Bartosz, M. Żurko (eds.), Badania narracyjne w psychologii. Warszawa: Wydawnictwo Psychologii i Kultury Eneteia.

Lalak, D. (2010). Życie jako biografia. Podejście biograficzne w perspektywie pedagogicznej. Warszawa: Wydawnictwo Akademickie Żak.

Malewski, M. (2012). Metodologia badań społecznych - ortodoksja i refleksyjność. Teraźniejszość - Człowiek Edukacja. 4(60), 29-46.

Malewski, M. (2017a). Badania jakościowe w metodologicznej pułapce scjentyzmu. Teraźniejszość - Człowiek Edukacja. 2(78), 129-136.

Malewski, M. (2017b). Badania jakościowe w naukach społecznych. O potrzebie metodologicznej wyobraźni. Teraźniejszość - Człowiek - Edukacja. 4(80), 105-120.

Mazurek, E. (2015). Lignes du développement (éducatif) dans les biographies - approche andragogique [in:] O. Czerniawska, A. Słowik (eds.). Trajets de formation et approche biographique. Perspectives française et polonaise. Paris: L'Harmattan.

Mazurek, E. (2017). Biograficzne uczenie się i narracyjne uczenie się - ramy teoretyczne. Edukacja Dorosłych. 1(76), 51-65.

Pryszmont-Ciesielska, M. (2016). Metodologiczny Hyde Park i kryzys badacza. Kulisy badań inspirowanych sztuką i performansem. Teraźniejszość - Człowiek - Edukacja. 3(75), 155-165.

Riessman, C. K. (2005). Narrative Analysis, [in:] Kelly N., Horrocks Ch., Milnes K., Roberts B., Robinson D. (eds.), Narrative, Memory \& Everyday Life, Huddersfield: University of Huddersfield, Huddersfield.

Tabor, U. (2008). Biograficzne uwarunkowania rozwoju nauczyciela. Analiza jakościowa. Katowice: Wydawnictwo Uniwersytetu Śląskiego.

Sladek, A. (2016). Autokreacja jako sposób doświadczania i budowania własnej dorosłości przez ludzi młodych, Edukacja Dorosłych, 2(75), 91-104.

Sladek, A. (2017). Między wymaganiami społecznymi a wizją samego siebie. Codzienność jako źródło autokreacji studentów [in:] M. Humeniuk, I. Paszenda (eds.). Codzienność jako wyzwanie edukacyjne, Wrocław: Instytut Pedagogiki Uniwersytetu Wrocławskiego.

Vynoslavska, O.V. (2003). Psyhologichni problemy realizacii' naukovo-pedagogichnymy pracivnykamy etychnyh norm profesijnoi' dijal'nosti. Visnyk NTUU “KPI”: Filosofija. Psyhologija. Pedagogika, 3(9), 101-110. 